\title{
RELATIONSHIP OF LEARNING STRATEGIES (PROBLEM SOLVING) WITH STUDENT LEARNING OUTCOMES IN FIKIH SUBJECT IN MAN 1 PADANGSIDIMPUAN
}

\author{
Rina Juliana \\ Dosen Universitas Muhammadiyah Tapanuli Selatan \\ Email: rinajulianaazkiya@gmail.com
}

\begin{abstract}
The problem faced by teachers in today's learning is determining the right strategy in learning. The learning strategies chosen by the teachers greatly influence student learning outcomes. Learning strategies that only attempt to spend the subject matter give less meaning to students. One strategy that can be used by teachers is problem solving learning strategies. In implementing this strategy utilizing is also very important for both teachers and students. Problem solving strategies are defined as a problem that is not routine, it is not yet known how to solve it. The problem raised in this study is whether there is a relationship between learning strategies to solve problems with student learning outcomes in the field of fiqh studies in MAN 1 Padangsidimpuan? The benefits to be achieved by researchers is for teachers to be able to apply learning strategies to problem solving in improving student learning outcomes. The purpose of this study was to determine the relationship between learning strategies to solve problems with student learning outcomes in the field of fiqh studies in MAN 1 Padangsidimpuan. To achieve these objectives this study uses a quantitative approach and the type of research is correlational. Data collection techniques through questionnaires and documentation. Validity test used Pearson product moment correlation formula, while the reliability test used alpha croanbach formula. To analyze the data used inferential descriptive method that is using simple correlation. The magnitude of the relationship of variables The magnitude of the relationship between learning strategy variables problem solving and student learning outcomes is 0.860 while the contribution of variable X1 with $Y$ is $73.96 \%$ then the remaining $26.04 \%$ is determined by other variables.
\end{abstract}

Keywords: Problem Solving Learning Strategies, Learning Outcomes

\section{PENDAHULUAN}

Salah satu faktor yang mempengaruhi hasil belajar siswa adalah guru. Guru yang dituntut di sini adalah guru yang memiliki kompetensi salah satunya kompetensi profesional. Salah satu contoh guru yang professional adalah dapat memanfatakan sumberbelajar dengan baik, salah satunya perpustakaan. Menurut UU Nomor 14 Tahun 2005 tentang Guru dan DosenPasal 1: "Guru adalah pendidik professional dengan tugas utama mendidik, mengajar, membimbing, mengarahkan, melatih, menilai, dan mengevaluasi peserta didik pada pendidikan anak usia dini jalur pendidikan formal, dasar, dan menengah. ${ }^{1}$

${ }^{1}$ Undang-Undang RI Nomor 14 Tahun 2005 Tentang Guru dan Dosen, (Jakarta: Sinar Grafika, 2008), h. 5 
Strategi pemecahan masalah didefinisikan sebagai suatu persoalan yang tidak rutin, belum dikenal cara penyelesaiaannya. Strategi pemecahan masalah adalah mencari atau menemukan cara penyelesaian (menemukan pola, aturan, atau algoritma). Sintaknya adalah menyajikan permasalahan yang memenuhi kriteria diatas, siswa berkelompok atau individual mengidentifikasi pola atau aturan yang disajikan, siswa mengidentifikasi, mengeksplorasi, menginvestigasi, menduga, dan akhirnya menemukan solusi.

Setiap strategi mempunyai kelebihan dan kelemahan. Tidak ada satu strategi yang paling baik dan tidak ada strategi yang paling buruk. Kebaikan suatu strategi tergantung kepada materi dan guru yang menggunakannya. Strategi pemecahan masalah memiliki keunggulan dalam meningkatkan hasil belajar siswa sebab memiliki motivasi yang kuat serta keluasaan dalam mengembangkan cara belajar yang aktif. Thorndike memandang belajar sebagai suatu usaha memecahkan masalah.

Selanjutnya agar strategi pembelajaran pemecahan masalah yang diterapkan guru dapat berlangsung secara efektif, maka siswa disuruh untuk memanfaatkan sumber belajar. Sumber belajar dapat dirumuskan sebagai segala usaha yang dapat memberikan kemudahan belajar, sehingga diperoleh sejumlah informasi, pengetahuan, pengalaman, dan keterampilan yang diperlukan.

Hasil belajar merupakan proses dalam diri individu yang berinteraksi dengan lingkungan untuk mendapatkan perubahan dalam perilakunya. Perubahan itu diperoleh melalui usaha (bukan karena kematangan), menetap dalam relatif lama dan merupakan hasil pengalaman. Hasil belajar juga merupakanmanifestasi perubahan baik ranah kognitif, afektif, dan psikomotor setelah proses pembelajaran berlangsung. Perpaduan antara ketiga hal tersebut melahirkan kompetensi siswa. Kompetensi yang dimiliki siswa dapat dilihat dari kesanggupannya untuk menyelesaikan tugas-tugas yang dibebankan kepadanya.

Berdasarkan observasi yang dilakukan peneliti dalam mengamati hasil belajar siswa dalam bidang studi fikih di MAN 1 Padangsidimpuan teridentifikasi bahwa rendahnya kemampuan siswa dalam memecahkan masalah yang berimplikasi pada hasil belajar siswa. Hal ini disebabkan karena kelemahan siswa dalam merumuskan masalah, menganalisis masalah, merumuskan hipotesis, mengumpulkan informasi yang berkaitan dengan materi fikih dan menguji hipotesi dimana siswa harus membandingkan hipotesis dengan data yang didapatkan siswa dalam memecahkan masalah fikih.

Hasil belajar siswa secara optimal merupakan tujuan yang hendak dicapai oleh semua lembaga pendidikan. Upaya untuk meningkatkan hasil belajar selalu dilakukan guru. Namun apa yang terjadi, bahwa harapan tersebut belum semuanya terpenuhi. Hasil belajar siswa belum memenuhi Standar Kriteria Minimum (SKM) dan Kriteria Ketuntasan Minimum (KKM). Hal inilah yang menjadi permasalahan. Masih dirasakan rendahnya daya simpan siswa terhadap materi pembelajaran salah satunya kemampuan siswa dalam memecahkan masalah dalam proses pembelajaran untuk menuntaskan SKM dan KKM.

Tabel 1. 
Al-Muaddib : Jurnal Ilmu-Ilmu Sosial \& Keislaman http://jurnal.um-tapsel.ac.id/index.php/al-muaddib/ issn online : 2549-0427 | issn cetak : 2528-2492 Volume 1 Nomor 2 ( Januari-Juni) 2019

Hasil belajar Fikih kelas X- XII Semester I Tahun Pelajaran 2018-20192

\begin{tabular}{|l|c|c|c|}
\hline & $\begin{array}{c}\text { Ulangan } \\
\text { Harian kelas } \\
\text { X }\end{array}$ & $\begin{array}{l}\text { Ulanga } \\
\text { n Harian XI }\end{array}$ & $\begin{array}{l}\text { Ula } \\
\text { ngan } \\
\text { Harian } \\
\text { XII }\end{array}$ \\
\hline KKM & 75 & 76 & 77 \\
\hline Rata-Rata Kelas & 72 & 74 & 75 \\
\hline Nilai Tertinggi & 88 & 90 & 90 \\
\hline Nilai Terendah & 45 & 55 & 65 \\
\hline Persentasi yang Tuntas & 67 & 64 & 65 \\
\hline $\begin{array}{l}\text { Persentasi yang tidak } \\
\text { Tuntas }\end{array}$ & 33 & 36 & 35 \\
\hline
\end{tabular}

Berdasarkan tabel di atas terlihat bahwa hasil ulangan harian yang telah dilaksanakan pada kelas X-XII MAN 1 Padangsidimpuan tersebut, nilai rata-rata kelas belum mencapai KKM yang ditetapkan, kemudian jumlah siswa yang tidak tuntas persentasinya cukup tinggi. Fakta ini menunjukkan bahwa dengan nilai ratarata mencapai KKM sedangkan peserta didik yang tidak tuntas persentasinya cukup tinggi, terdapat perbedaan yang cukup besar hasil belajar peserta didik kelas X-XII dalam bidang studi fikih di MAN 1 Padangsidimpuan.

Berdasarkan studi pendahuluan yang dilakukan penulis bahwa strategi pembelajaran pemecahan masalah sudah diterapkan di MAN 1 Padangsidimpuan. Langkah-langkah yang terdapat dalam strategi pembelajaran pemecahan masalah sudah dilaksanakan oleh guru dalam bidang studi fikih. Guru bidang studi fikih di MAN 1 berjumlah empat orang dan keempatnya mengajar pada kelas X, XI, dan XII baik yang kelas yang unggulan maupun yang reguler.

Dengan demikian, persoalan-persoalan tersebut masih membutuhkan jawaban, dimana adanya kesenjangan antara hasil belajar dengan strategi pembelajaran pemecahan masalah di MAN 1 Padangsidimpuan. Seharusnya dengan adanya strategi pemecahan masalah yang baik dan guru dapat memotivasi siswa untuk dapat memanfaatkan sumber belajar agar siswa dapat mendayagunakannya dengan baik dan ini akan berimplikasiterhadap peningkatan hasil belajar siswa khususnya dalam bidang studi fikih, tetapi realitanya masih banyak hasil belajar siswa yang belum tuntas. Berdasarkan hal demikian maka jelas ada masalah yaitu adanya kesenjangan antara teori dan fakta. Berdasarkan uraian di atas maka penulis ingin meneliti tentang "Hubungan Strategi Pembelajaran Pemecahan Masalah (Problem Solving) Dengan Hasil Belajar Siswa Bidang Studi Fikih di MAN 1 Padangsidimpuan.

\section{Pengertian Strategi Pembelajaran Pemecahan Masalah}

Istilah strategi pada mulanya digunakan dalam dunia militer yang diartikan sebagai cara penggunaan seluruh kekuatan militer untuk memenangkan suatu peperangan. Dalam dunia pendidikan strategi diartikan sebagai a plan, method, or series of activities designed to achieves a

\footnotetext{
${ }^{2}$ Sumber: Daftar Nilai Guru Fikih kelas X-XII MAN 1 Padangsidimpuan.
} 
Al-Muaddib : Jurnal Ilmu-Ilmu Sosial \& Keislaman http://jurnal.um-tapsel.ac.id/index.php/al-muaddib/ issn online : 2549-0427 | issn cetak : 2528-2492 Volume 1 Nomor 2 (Januari-Juni) 2019

particular educational goal. Jadi dengan demikian strategi pembelajaran dapat diartikan sebagai perencanaan yang berisi tentang rangkaian kegiatan yang didisain untuk mencapai tujuan pendidikan tertentu.

Strategi secara umum dapat didefinisikan sebagai garis besar haluan bertindak untuk mencapai sasaran yang telah ditetapkan. Secara umum strategi mempunyai pengertian suatu garis besar haluan untuk bertindak dalam usaha mencapai sasaran yang ditentukan. Berkaitan dengan pembelajaran strategi dapat diartikan sebagai pola-pola umum kegiatan guru dengan anak didik dalam perwujudan kegiatan pembelajaran untuk mencapai tujuan yang telah digariskan. ${ }^{3}$

Menurut Wina Sanjaya, ${ }^{4}$ istilah strategi dalam konteks belajar mengajar, strategi berarti pola umum perbuatan guru peserta didik di dalam perwujudan kegiatan belajar mengajar. Sifat umum pola tersebut berarti bahwa macam dan urutan perbuatan yang dimaksud tampak dipergunakan dan/dipercayakan guru-peserta didik di dalam bermacam-macam peristiwa belajar. Dengan demikian maka konsep strategi dalam hal ini menunjuk pada karakteristik abstrak rentetan perbuatan guru-peserta didik di dalam peristika belajar mengajar. Implisit di balik karakteristik abstrak itu adalah rasional yang membedakan strategi yang satu dari strategi yang lain secara fundamental. Istilah lain yang juga digunakan untuk maksud ini adalah model-model mengajar. Sedangkan rentetan perbuatan guru-peserta didik dalam suatu peristiwa belajar mengajar aktual tertentu, dinamakan prosedur instruksional.

Strategi dalam pembelajaran adalah segala yang dapat diberdayakan guru demi suksesnya sebuah pembelajaran. Strategi bersifat tidak langsung (indirect) dalam kaitannya dengan suksesnya pembelajaran. Sedangkan yang bersifat langsung (direct) adalah metode, karena dilakukan oleh seorang guru dalam sebuah peristiwa pembelajaran. ${ }^{5}$

Secara umum pemecahan masalah berkaitan dengan penanganan tugas yang baru dan tidak terbiasa saat metode solusi yang relevan. Pada awalnya proses yang dibahas adalah riset kognitif adalah proses yang terlibat dalam pemecahan masalah yang tidak berkaitan dengan pelajaran sekolah. ${ }^{6}$

Wallas describe problem solving as a four step process: preparation, incubation, illumination, and verification. Preparation consist od defining and studying the problem, incubation involves a period of not working on the problem, illumination consist of identifying a possible solution, and verification involves testing the solution. Illumination was seen as an experience of insight, which was defined as a sudden discovery of the correct

\footnotetext{
${ }^{3}$ Yatim Riyanto, op.cit., h. 131

${ }^{4}$ Wina Sanjaya, Strategi Pembelajaran Beriorentasi Standar Proses Pendidikan, (Jakarta: Kencana, 2010), h. 126

${ }^{5}$ Ibid.

${ }^{6}$ Margaret E. Gredler, Leraning and Instruction: Teori dan Aplikasi, (Jakarta: Kencana, 2011), h. 284
} 
Al-Muaddib : Jurnal Ilmu-Ilmu Sosial \& Keislaman http://jurnal.um-tapsel.ac.id/index.php/al-muaddib/ issn online : 2549-0427 | issn cetak : 2528-2492 Volume 1 Nomor 2 ( Januari-Juni) 2019

solution following a period of incorect attempts based primarily on trial and error. $^{7}$

Strategi pemecahan masalah didefinisikan sebagai suatu persoalan yang tidak rutin, belum dikenal cara penyelesaiaannya. Strategi pemecahan masalah adalah mencari atau menemukan cara penyelesaian (menemukan pola, aturan, atau algoritma). Sintaknya adalah sajikan permasalahan yang memenuhi kriteria diatas, siswa berkelompok atau individual mengidentifikasi pola atau aturan yang disajikan, siswa mengidentifikasi, mengeksplorasi, menginvestigasi, menduga, dan akhirnya menemukan solusi. ${ }^{8}$ Masalah dalam kurikulum sekolah biasanya memiliki komponen spesifik dan bisa diklasifikasikan berdasarkan sifat dari masalah atau tingkatan pengalaman pembelajaran dengan jenis masalah tertentu.

Pemecahan masalah melibatkan penempatan para siswa dalam peran aktif berhadapan dengan masalah baru yang ditemukan dalam kehidupan. Para siswa mulai dengan pengetahuan terbatas, tetapi melalui kolaborasi dengan rekan, penelitian dan konsultasi dengan ahli, mereka mengembangkan, menjelaskan, dan mempertahankan solusi atau posisi mengenai masalah tersebut. ${ }^{9}$

A significant problem that one encounters when attempting to implement the above recommendations is the decision as to what constututes problem solving. The renoened master teacher af problem solving, Georgian Polya, states, "to have a problem means to search consciously for some action appropriate to attain some clearly conceived but not immediately attainable aim. ${ }^{10}$

Dalam defenisi formalnya masalah mengandung tiga komponen: ketentuan, tujuan, dan kegiatan yang dibolehkan. Ketentuan adalah unsur, relasi antar unsur, dan kondisi atau batasan yang menciptakan bentuk awal dari masalah. Tujuan adalah hasil yang diinginkan atau solusi, dan kegiatan yang dibolehkan adalah langkah-langkah atau prosedur yang akan mengubah ketentuan menjadi tujuan. ${ }^{11}$

Prinsip dasar dalam strategi pemecahan masalah adalah perlunya aktivitas dalam mempelajari sesuatu. jika guru menjelaskan bahan pelajaran bagi siswa dan masyarakat. Strategi pemecahan masalah merupakan strategi dalam kegiatan pembelajaran dengan jalan melatih siswa menghadapi berbagai masalah, baik masalah pribadi maupun masalah kelompok untuk dipecahkan sendiri atau secara bersama-sama. Orientasi pembelajarannya

\footnotetext{
${ }^{7}$ Richard Hamilton dan Elizabeth Ghatala, Learning ang Instruction, (New York: McGraw-Hill, 1994), h. 169

${ }^{8}$ Ngalimun, Strategi dan Model Pembelajaran, (Yogyakarta: Aswaja Pressindo, 2013), h. $14-15$

${ }^{9}$ Sharon E. Smaldino, Instructional Technology dan Media For Learning: Teknologi Pembelajaran dan Media Untuk Belajar, (Jakarta: Kencana, 2012), h. 47

${ }^{10}$ Daniel T Dolan and James Williamson, Teaching Problem Solving Strategies, (New Yorka: Addision-Weley Publishing Company, 1983), h. 9

${ }^{11}$ Margaret E. Gredler, op.cit., h. 228
} 
adalah investigasi dan penemuan yang pada dasarnya adalah pemecahan masalah. ${ }^{12}$

Dengan demikain strategi pembelajarn pemecahan masalah adalah suatu kegiatan belajar yang mengharuskan peserta didik menemukan jawabannya tanpa bantuan khusus. Dengan memecahkan masalah peserta didik menemukan aturan baru yang lebih tinggi tarafnya sekalipun ia mungkin tidak dapat merumuskannya secara verbal. Pemecahan masalah yang dipecahkan sendiri, yang ditemukan sendiri tanpa bantuan khusus, memberi hasil yang lebih unggul yang digunakan dalam situasi-situasi lain. Karena itu bagi pendidikan sangatlah penting untuk mendorong anak menemukan penyelesaian soal dengan pemikiran sendiri.

\section{Keunggulan dan Kelemahan Strategi Pembelajaran Pemecahan Masalah}

Keunggulan strategi pembelajaran pemecahan masalah adalah sebagai berikut:

a. Melatih siswa untuk mendesain suatu penemuan.

b. Berpikir dan bertindak kreatif.

c. Memecahkan masalah yang dihadapi secara realistis.

d. Mengidentifikasi dan melakukan penyelidikan.

e. Menafsirkan dan mengevalusi hasil pengamatan.

f. Merangsang perkembangan kemajuan berpikir siswa untuk menyeleseaikan masalah yang dihadapi dengan tepat.

g. Dapat membuat pendidikan sekolah lebih relevan dengan kehidupan khusunya dunia kerja. ${ }^{13}$

Selanjutnya kelemahan strategi pembelajaran pemecahan masalah adalah sebagai berikut:

a. Memerlukan waktu yang lama.

b. Siswa yang pasif dan malas akan tertinggal.

c. Sukar sekali untuk mengorganisasikan bahan pelajaran.

\section{Cara Melakukan Startegi Pembelajaran Pemecahan Masalah}

Startegi pembelajaran pemecahan masalah dapat dilakukan dengan berbagai cara antara lain sebagai berikut:

a. Pemecahan masalah berdasarkan pengalaman masa lampau. Biasanya cara ini digunakan pada masalah-masalah yang muncul secara berkala yang hanya berbeda dalam bentuk penampilannya. Apabila cara-cara yang digunakan ini melembaga maka cara pemecahan masalah ini disebut cara tradisional. Dalam hal ini pemecahan masalah menjadi kurang (tidak) rasional.

b. Pemecahan masalah secara intuitif. Masalah diselesaikan tidak berdasarkan akal, tetapi berdasarkan intuisi atau firasat.

c. Pemecahan masalah dengan cara trial dan eror. Pemecahan masalah dilakukan dengan coba-coba sehingga akhirnya ditemukan pemecahan

\footnotetext{
${ }^{12}$ Hamdani, op.cit., h. 84

${ }^{13}$ Ibid.
} 
yang tepat. Percobaan yang dilakukan tidak berdasarka hipotesis, tetapi secara acak.

d. Pemecahan masalah secara otoritas. Pemecahan masalah dilakukan berdasarkan kewenangan seseorang.

e. Pemecahan masalah secara metafisik. Masalah-masalah yang dihadapi dalam dunia empirik dipecahkan dengan konsep-konsep atau prinsipprinsip yang bersumber daklam dunia supranatural atau dunia mistik atau dunia gaib.

f. Pemecahan masalah secara ilmiah ialah pemecahan masalah secara rasional melalui proses deduksi dan induksi. Pemecahan masalah yang dibicarakan dalam strategi belajar mengajar disini ialah pemecahan masalah secara ilmiah atau semi ilmiah. Untuk mendukung strategi belajar mengajar ini guru perlu memilih bahan pelajaran yang memiliki permasalahan. ${ }^{14}$

\section{Hasil Belajar}

Hasil belajar dapat dijelaskan dengan memahami dua kata yang membentuknya, yaitu “ hasil” dan “ belajar”. Pengertian hasil menunjuk pada suatu perolehan akibat dilakukannya suatu aktivitas atau proses yang mengakibatkan berubahnya input secara fungsional. Belajar dilakukan untuk mengusahakan adanya perubahan perilaku pada individu yang belajar. Perubahan perilaku itu merupakan perolehan yang menjadi hasil belajar. Belajar itu merupakan perubahan perilaku sebagai hasil dari pengalaman. Belajar yang sebaik-baiknya adalah dengan mengalami sesuatu yaitu menggunakan pancaindra. Dengan kata lain, bahwa belajar adalah suatu cara mengamati, membaca, meniru, mengintisimasi, mencoba sesuatu, mendengar dan mengikuti arah tertentu. ${ }^{15}$ Dengan demikian hasil belajar adalah perubahan yang mengakibatkan manusia berubah dalam sikap dan tingkah lakunya. ${ }^{16}$

Di dalam al-Qur'an kata hasil belajar tersebar dalam beberapa surah seperti kata al-inba', al-hisab, al-wazn, al-bala', al-wazn, al-taqdir, dan annadzr.Kata al-inba' terdapat dalam surat al-Baqarah ayat 31 dan 33, Allah berfirman:

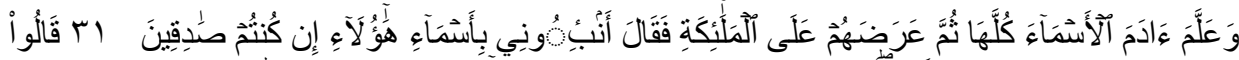

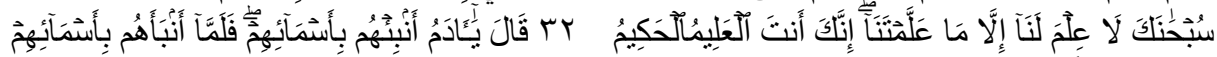

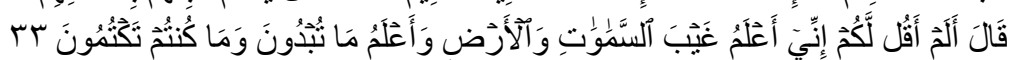

Artinya: Dan Dia mengajarkan kepada Adam Nama-nama (benda-benda) seluruhnya, kemudian mengemukakannya kepada Para Malaikat lalu berfirman: "Sebutkanlah kepada-Ku nama benda-benda itu jika kamu mamang benar orang-orang yang benar!" Mereka menjawab: "Maha suci

\footnotetext{
${ }^{14}$ W. Gulo, Strategi Belajar Mengajar, (Jakarta: Gramedia Widya Sarana Indonesia, 2002), h. 113-114

${ }^{15}$ Yatim Riyanto, Paradigma Baru Pembelajaran: Sebagai Referensi Bagi Guru Pendidik dalam Implementasi Pembelajaran Yang Efektif dan Berkualitas, (Jakarta: Kencana, 2009), h. 5

${ }^{16}$ Ibid., h. 44-45
} 
Engkau, tidak ada yang Kami ketahui selain dari apa yang telah Engkau ajarkan kepada kami; Sesungguhnya Engkaulah yang Maha mengetahui lagi Maha Bijaksana."Allah berfirman: "Hai Adam, beritahukanlah kepada mereka Nama-nama benda ini." Maka setelah diberitahukannya kepada mereka Nama-nama benda itu, Allah berfirman: "Bukankah sudah Ku katakana kepadamu, bahwa Sesungguhnya aku mengetahui rahasia langit danbumidan mengetahui apa yang kamu lahirkan dan apa yang kamu sembunyikan?"

Ayat ini menurut Quraish sihab menginformasikan bahwa manusia dianugrahi Allah potensi untuk mengetahui nama atau fungsi dan karakter setiap benda-benda misalnya fungsi api, fungsi angin dan sebagainya. Dia juga dianugerahi potensi untuk berbahasa. Sistem pengajaran bahasa kepada manusia (anak kecil) bukan dimulai dengan mengajarkan kata kerja tetapi mengajarkannya terlebih dahulu nama-nama. Itulah sebagian makna yang dipahami oleh para ulama. Selanjutnya beliau mengemukakan bahwa keistimewaan manusia adalah kemampuannya mengekspresikan apa yang terlintas dalam benaknya serta kemampuannya menangkap bahasa, sehingga ini menghantarkannya "mengetahui”. Di sisi lain, kemampuan manusia merumuskan ide dan memberi nama bagi segala sesuatu merupakan langkah menuju terciptanya manusia berpengetahuan dan lahirnya ilmu pengetahuan. ${ }^{17}$ Menurut Imam as-Suyuti ayat di atas menjelaskan bahwa Allah telah mengajarkan kepada Adam nama-nama semua makhluk ciptaan-Nya seperti manusia, hewan, bumu, lautan, gunung, dan lain sebagainya. ${ }^{18}$

\section{METODOLOGI PENELITIAN}

\section{Lokasi dan Waktu Penelitian}

Lokasi penelitian ini ditentukan di MAN 1 Padangsidimpuan, Jalan Sutan Soripada Mulia No. 31 C, Kelurahan Sihadabuan, Kecamatan Padangsidimpuan Utara, Kota Padangsidimpuan, Provinsi Sumatera Utara. Penelitian ini mulai dilaksanakan semenjak proposal ini diterima.

\section{Pendekatan, Jenis dan Metode Penelitian}

Dari segi pendekatan, penelitian ini termasuk penelitian kuantitatif. Penelitian kuantitatif adalah penelitian yang mementingkan kedalaman data, penelitian kuantitatif tidak terlalu menitikberatkan pada kedalaman data, yang penting dapat merekam data sebanyak-banyaknya dari populasi yang luas. Walaupun populasi penelitian besar, tetapi dengan mudah dapat dianalisis, baik melalui rumus-rumus statistik.

Berdasarkan jenis dan metode pengumpulan data penelitian ini termasuk penelitian korelasional. Penelitian korelasional menggambarkan suatu pendekatan umum untuk penelitian yang berfokus pada penaksiran pada kovariasi di antara

\footnotetext{
${ }^{17}$ M. Quraish Shihab, Tafsir al-Misbah: Pesan, Kesan, dan Keserasian al-Qur'an, Volume: 1, (Jakarta: Lentera Hati, 2004), h. 143-144

${ }^{18}$ Imam Jalaluddin Abdurrahman bin Abi Bakr as-Suyuthi, Ad-Durru al-Mantsur fi Tafsir al-Ma'tsur, (Beirut: Dar-al-Kutub al-‘Alamiyah, 2000), h. 101
} 
variabel yang muncul secara alami. Tujuan penelitian korelasional adalah untuk mengidentifikasi hubungan prediktif dengan menggunakan teknik korelasi atau teknik statistik. ${ }^{19}$

Penelitian korelasional ditujukan untuk mengetahui hubungan suatu variabel dengan variabel lain. Hubungan antara satu dengan beberapa variabel lain dinyatakan dengan besarnya koefisien korelasi dan keberartian (signifikansi) secara statistik. Adanya korelasi antara dua variabel atau lebih, tidak berarti adanya pengaruh atau hubungan sebab-akibat dari suatu variabel terhadap variabel lainnya.

\section{Populasi dan Sampel}

Populasi adalah kelompok besar dan wilayah yang menjadi lingkup penelitian. ${ }^{20}$ Populasi dalam penelitian ini adalah siswa MAN 1 Padangsidimpuan yang berjumlah 992 orang. Selanjutnya sampel ialah kelompok kecil yang secara nyata diteliti dan ditarik kesimpulan daripadanya. ${ }^{21}$ Dalam penentuan sampel pada penelitian ini maka peneliti menggunakan teknik probability sampling. Probability Sampling merupakan metode sampling yang setiap anggota populasi memiliki peluang yang sama untuk terpilih sebagai sampel. $^{22}$

Teknik sampling yang digunakan pada penelitian ini adalah stratified random sampling. Alasan peneliti menggunakan teknik sampling ini dikarenakan populasi yang digunakan bersifat heterogen, yaitu karakteristik populasi yang bervariasi. ${ }^{23}$ Dengan demikian jumlah sampel dalam penelitian ini adalah 91 orang.

\section{Instrumen Pengumpulan Data}

Untuk mengumpulkan data maka diperlukan teknik pengumpulan data pada penelitian ini. Teknik pengumpulan data merupakan bagian instrumen pengumpulan data yang menentukan berhasil atau tidaknya suatu penelitian. Instrumen pengumpulan data yang digunakan peneliti yaitu dengan menggunakan angket.

Angket adalah sejumlah pertanyaan tertulis yang digunakan untuk memperoleh informasi dari responden dalam arti laporan tentang pribadinya atau hal-hal yang ia ketahui. ${ }^{24}$ Instrumen pengumpulan data kedua yang digunakan pada penelitian ini adalah dokumen yaitu hasil dari ulangan siswa ataupun dokumentasi nilai harian siswa. Dokumen yang digunakan untuk melihat hasil belajar itu ialah berupa nilai hasil ulangan harian siswa.

\section{Teknik Pengolahan dan Analisis Data}

\footnotetext{
${ }^{19}$ Emzir, Metodologi Penenlitian Pendidikan Kuantitatif dan Kualitatif, (Jakarta: PT RajaGrafindo Persada, 2010), Cet. ke-4, h. 37

${ }^{20}$ Nana Syaodih Sukmadinata, op.cit., h. 250

${ }^{21}$ Ibid., h. 251

${ }^{22}$ Syofian Siregar, Metode Penelitian Kuantitatif: Dilengkapi Perhitungan Manual dan SPSS, (Jakarta: Kencana, 2014), h. 31

${ }^{23}$ Bambang Prasetyo dan Lina Miftahul Jannah, Metode Penelitian Kuantitatif: Teori dan Aplikasi, (Jakarta: Raja Grafindo Persada, 2005), h. 130

${ }^{24}$ Suharsimi Arikunto, Prosedur Penelitian Suatu Pendekatan Praktik, (Jakarta: Rineka Cipta, 2006), h. 137
} 
Sebelum data mentah siap dianalisis, terutama analisis statistik, maka data mentah tersebut perlu diolah dahulu untuk menjamin keakuratan datanya, yaitu dengan beberapa langkah pokok sebagai berikut:
a. Ceking Data
b. Editing Data
c. Coding Data
d. Tabulating Data
Analisis data yang digunakan pada penelitian ini adalah dengan menggunakan rumus korelasi sederhana.

\section{Teknik Penjaminan Keabsahan Data}

\section{a. Uji Validitas}

Teknik pengujian keabsahan data pada pendekatan kuantatif dikenal dengan istilah uji validitas dan reliabilitas. Validitas adalah salah satu ciri yang menandai tes hasil belajar yang baik. ${ }^{25}$ Uji Validitas dilakukan dengan menggunakan rumus Korelasi Perason Product Moment.

\section{b. Uji Reliabilitas}

Realibiltas instrumen berkenaan dengan tingkat keajegan atau ketetapan hasil pengukuran. Suatu instrumen memiliki tingkat reliabilitas yang memadai, bila instrumen tersebut digunakan mengukur aspek yang diukur beberapa kali hasilnya sama atau relatif. Uji Reliabilitas dilakukan dengan menggunakan rumus Alpha Croanbach.

\section{HASIL DAN PEMBAHASAN PENELITIAN}

Untuk melakukan pengujian hipotesis yang diajukandalam penelitian ini, sebagaimana yang diolah menggunakan rumus korelasi sederhana. Dalam kajian teoritis yang dilakukan pada bagian terdahulu, penulis mempunyai dugaan yang kuat bahwa "Terdapat Hubungan Strategi pembelajaran pemecahan masalah dengan Hasil Belajar Siswa dalam Mata Pelajaran Fikih di MAN 1 Padangsidimpuan”

Dari rekapitulasi hasil angket di atas selanjutnya dilakukan perhitungan untuk memperoleh hasil angket rata-rata (mean), hasil angket tengah (median), dan hasil angket yang paling sering muncul (modus), standar deviasi, range, nilai minimum, nilai maksimum, dan juga sum yang dalam hal ini diolah dengan menggunakan SPSS 22,0 sebagaimana yang terdapat di bawah ini:

Tabel 3

Rangkuman Deskripsi Data Angket Terhadap Strategi Pembelajaran Pemecahan Masalah di MAN 1Padangsidimpuan dengan Menggunakan SPSS 22.0

\begin{tabular}{|c|c|c|}
\hline Nilai & Frequensi & $\%$ \\
\hline $169-178$ & 2 & $2,19 \%$ \\
\hline $158-168$ & 8 & $8,79 \%$ \\
\hline $147-157$ & 11 & $12,08 \%$ \\
\hline $136-146$ & 24 & $26,37 \%$ \\
\hline
\end{tabular}

${ }^{25}$ Anas Sudijono, Pengantar Evaluasi Pendidikan,(Jakarta: Raja Grafindo Persada, 2012), h. 163 
Al-Muaddib : Jurnal Ilmu-Ilmu Sosial \& Keislaman http://jurnal.um-tapsel.ac.id/index.php/al-muaddib/ issn online : 2549-0427 | issn cetak : 2528-2492 Volume 1 Nomor 2 (Januari-Juni) 2019

\begin{tabular}{|c|c|c|}
\hline $125-135$ & 37 & $40,65 \%$ \\
\hline $114-124$ & 7 & $7,69 \%$ \\
\hline $104-113$ & 1 & $1,09 \%$ \\
\hline $93-103$ & 1 & $1,09 \%$ \\
\hline Interval= 10 & 91 & $100 \%$ \\
\hline
\end{tabular}

Dari tabel data di atas diketahui bahwa skor terendah variabelstrategi pembelajaran pemecahan masalah, berdasarkan hasil jawaban siswa di MAN 1 Padangsidimpuan sebanyak 91 orang sampel diperoleh skor maksimum sebesar 178 , skor minimum 99 , mean 137,2688 , median 135,00 , modus 126,00 , standar deviasi 14,61174, variance 213,503, range 79, dan sum 12766.

Hasil Analisis Korelasi Sederhana X1 Terhadap Y Model Summary ${ }^{\mathrm{b}}$

\begin{tabular}{|c|c|c|c|c|c|c|c|c|c|c|}
\hline \multirow[b]{2}{*}{$\begin{array}{l}\text { Mode } \\
1\end{array}$} & \multirow[b]{2}{*}{$\mathrm{R}$} & \multirow[b]{2}{*}{$\begin{array}{l}\mathrm{R} \\
\text { Squa } \\
\text { re }\end{array}$} & \multirow[b]{2}{*}{$\begin{array}{l}\text { Adjust } \\
\text { ed R } \\
\text { Square }\end{array}$} & \multirow{2}{*}{$\begin{array}{l}\text { Std. } \\
\text { Error of } \\
\text { the } \\
\text { Estimat } \\
\text { e }\end{array}$} & \multicolumn{5}{|c|}{ Change Statistics } & \multirow[b]{2}{*}{$\begin{array}{l}\text { Durbin- } \\
\text { Watson }\end{array}$} \\
\hline & & & & & $\begin{array}{c}\mathrm{R} \\
\text { Square } \\
\text { Chang } \\
\text { e }\end{array}$ & F Change & df1 & $\mathrm{df} 2$ & $\begin{array}{c}\text { Sig. F } \\
\text { Chang } \\
\text { e }\end{array}$ & \\
\hline 1 & $\begin{array}{r}.860 \\
\text { a }\end{array}$ & .007 & .416 & $\begin{array}{r}14.2741 \\
8\end{array}$ & .007 & .668 & 1 & 89 & .416 & 1.552 \\
\hline
\end{tabular}

a. Predictors: (Constant), VAR00003

b. Dependent Variable: VAR00001

Dari tabel di atas dapat diketahui bahwa koefisien korelasi antara strategi pembelajaran pemecahan masalah terhadap hasil belajar dalam bidang studi fikih di MAN 1 Padangsidimpuansebesar 0,86.Untuk menguji hipotesis, maka nilai $r$ hitung $\left(\mathrm{r}_{\mathrm{xy}}\right)$ dikonsultasikan kepada $\mathrm{r}$ tabel $\left(\mathrm{r}_{\mathrm{t}}\right)$, yaitu $\mathrm{N}-\mathrm{nr}=91-2=89$. Pada tabel "r" Product Moment ditemukan nilai $\mathrm{r}$ tabel $\left(r_{t}\right)$ untuk df $=89$ pada tingkat kepercayaan 5\% sebesar 0,213. Dengan demikian hipotesis yang berbunyi "terdapat hubungan strategi pembelajaran pemecahan masalah terhadap hasil belajar dalam bidang studi fikih di MAN 1 Padangsidimpuan"diterima karena $r$ hitung $\left(r_{x y}=0860>r_{t}=0,213\right)$. Artinya semakin lamastrategi pembelajaran pemecahan masalah yang dilakukan guru bidang studi fikih maka akan semakin baik hasil belajar siswa di MAN 1 Padangsidimpuan.

Kemudian untuk melihat seberapa besar kontribusi strategi pembelajaran pemecahan masalah dan pemanfaatan perpustakaan dengan hasil belajar siswa dalam bidang studi fikih di MAN 1 Padangsidimpuan maka digunakan rumus koefesien determinan. Adapun rumus yang digunakan adalah sebagai berikut:

$\mathrm{Kp}=$ nilai koefisien diterminan

$r=$ nilai koefisien korelasi 
Al-Muaddib : Jurnal Ilmu-Ilmu Sosial \& Keislaman http://jurnal.um-tapsel.ac.id/index.php/al-muaddib/ issn online : 2549-0427 | issn cetak : 2528-2492 Volume 1 Nomor 2 ( Januari-Juni) 2019

$$
\begin{aligned}
\mathrm{Kp}=\boldsymbol{r}^{\mathbf{2}} \boldsymbol{x} \mathbf{1 0 0} \% & =\mathbf{0 , 8 6 0} \mathbf{2}^{2} \times 100 \% \\
& =0,7396 \\
& =73,96 \%(\mathrm{X} 1 \text { dan } \mathrm{Y})
\end{aligned}
$$

Berdasarkan perhitungan di atas, maka dapat diketahui bahwa kontribusi yang diberikan strategi pembelajaran pemecahan masalah adalah sebesar 73,96\% terhadap hasil belajar siswa, dan selebihnya dipengaruhi oleh variabel lain. Selanjutnya kontribusi yang diberikan pemanfataan perpustakaan adalah 48,30\% terhadap hasil belajar siswa, dan selebihnya dipengaruhi oleh variabel lain.

Penelitian berjudul tentang hubungan strategi pembelajaran pemecahan masalah terhadap hasil belajar siswa dalam bidang studi fikih di MAN 1 Padangsidimpuan merupakan salah satu penelitian yang bertujuan untuk menguji kebenaran teori terhadap kondisi yang terjadi di lapangan dengan menggunakan rumus statistic atau yang dikenal dengan jenis penelitian kuantitatif. Penulis tertarik mengangkat judul penelitian tersebut dilatarbelakangi untuk menguji sebuah teori. Teori ini direduksi dalam konteks pembelajaran di MAN 1 Padangsidimpuan, akan tinggi.

Pembahasan mengenai strategi pembelajaran pemecahan masalah berpengaruh dan signifikan terhadap hasil belajar siswa, secara psikologis menurut Gagne, belajar merupakan kegiatan yang kompleks. Hasil belajar berupa kapabilitas. Setelah belajar orang memiliki keterampilan, pengetahuan, sikap, dan nilai. Timbulnya kapabilitas tersebut adalah dari: a. Stimulasi yang berasal dari lingkungan, b. Proses kognitif yang dilakukan oleh si pengajar. Dengan demikian demikian belajar adalah seperangkat proses kognitif yang mengubah sifat stimulasi lingkungan melalui pengolahan informasi, menjadi kapabilitas baru.

Selanjutnya pembelajaran secara umum adalah kegiatan yang dilakukan guru sehingga tingkah laku siswa berubah ke arah yang lebih baik. Pembelajaran juga merupakan upaya guru menciptakan iklim dan pelayanan terhadap kemampuan, potensi, minat, bakat, dan kebutuhan siswa yang amat beragam agar terjadi interaksi optimal antara guru dengan siswa ataupun antara siswa dengan guru.

Dalam hasil belajar, siswa dipengaruhi oleh banyak faktor. Oleh kaena itu siswa harus mengetahui faktor-faktor yang dimaksud, demikian juga para pendidik, pembimbing, dan pengajar di dalam mengatur dan mengendalikan faktor-faktor tersebut yang mempengaruhi proses pembelajaran sehingga proses pembelajarandapat berjalan secara optimal.

Guru adalah variabel bebas yang mempengaruhi kualitas pengajaran. Hal ini karena guru adalah sutradara dan sekaligus aktor 
dalam proses pengajaran. Kompetensi profesional yang dimiliki guru sangat dominan untuk mempengaruhi kualitas pembelajaran. Maksudnya penggunaan strategi pembelajaran yang digunakan guru seperti strategi pembelajaran pemecahan masalah sagat mempengaruhi hasil belajar siswa. Dalam proses belajar agar siswa dapat menerima, menguasai, dan lebih mengembangkan bahan pelajaran itu, guru harus mengajara dengan cara yang tepat, efektif, dan efisien.

Dari uraian di atas, jelas bahwa penggunaan strategi pembelajaran dapat mempengaruhi hasil belajar siswa. Salah satunya strategi pembelajaran pemecahan masalah. Strategi pembelajaran ini menyajikan pelajaran dengan mendorong siswa untuk mencari dan memecahkan suatu masalah atau persoalan dalam rangka pencapaian tujuan pembelajaran. Tujuan pembelajaran itu tercapai dapat diketahui dari hasil belajar siswa yang baik.

\section{KESIMPULAN}

Strategi pembelajaran pemecahan masalah berhubungan secara signifikan dengan hasil belajar siswa. Besarnya hubungan variabel strategi pembelajaran pemecahan masalah terhadap hasil belajar siswa adalah 0,860 sedangkan kontribusi variabel X1 terhadap Y sebesar 73,96\% kemudian sisanya 26,04\% ditentukan oleh variabel lain. Informasi ini memberikan keterangan bahwa variabel strategi pembelajaran pemecahan masalah memberikan hubungan kuat terhadap hasil belajar siswa. Informasi ini memberikan keterangan bahwa variabel strategi pembelajaran pemecahan masalah memberikan hubungan kuat terhadap hasil belajar siswa. Data empiris telah membuktikan bahwa pemanfataan perpustakaan dapat meningkatkan hasil belajar siswa dalam mata pelajaran Fikih di MAN 1 Padangsidimpuan. Dalam hal ini ada beberapa saran yang dapat peneliti ajukan:

a. Kepada siswa diharapkan untuk lebih aktif dan giat, agar criteria ketuntasan minimal yang ditetapkan dapat tercapai dalam mata pelajaran Fikih.

b. Kepada para guru bidang studi Fikih agar dapat mengaplikasikan strategi pembelajaran pemecahan masalah agar pembelajaran tidak monoton dan diharapkan dapat meningkatkan hasil belajar siswa.

c. Kepada para siswa dan siswi di MAN 1 Padangsidimpuan agar lebih termotivasi dalam mengikuti proses pembelajaran.

d. Kepada kepala Sekolah MAN 1Padangsidimpuan diharapkan dapat membekali dan menambah pengetahuan para guru dan siswa tentang pelaksanaan strategi pembelajaran yang baik.

e. Kepada peneliti ada kemungkinan kelemahan yang terjadi dalam pelaksanaan penelitian ini, maka perlu kiranya diadakan penelitian lebih lanjut dengan memperbesar objek penelitian.

f. Begitu juga dengan peneliti yang berminat untuk meneliti lebih lanjut masalah dalam penelitian ini supaya memperhatikan variabel lain yang mungkin turut berhubungan terhadap hasil belajar siswa. 
Al-Muaddib : Jurnal Ilmu-Ilmu Sosial \& Keislaman http://jurnal.um-tapsel.ac.id/index.php/al-muaddib/ issn online : 2549-0427 | issn cetak : 2528-2492 Volume 1 Nomor 2 (Januari-Juni) 2019

\section{DAFTAR PUSTAKA}

Anas Sudijono, Pengantar Evaluasi Pendidikan, Jakarta: Raja Grafindo Persada, 2012.

Bambang Prasetyo dan Lina Miftahul Jannah, Metode Penelitian Kuantitatif: Teori dan Aplikasi, Jakarta: Raja Grafindo Persada, 2005.

Daniel T Dolan and James Williamson, Teaching Problem Solving Strategies, New Yorka: Addision-Weley Publishing Company, 1983.

Emzir, Metodologi Penenlitian Pendidikan Kuantitatif dan Kualitatif, Jakarta: PT RajaGrafindo Persada, 2010.

Imam Jalaluddin Abdurrahman bin Abi Bakr as-Suyuthi, Ad-Durru al-Mantsur fi Tafsir al-Ma’tsur, Beirut: Dar-al-Kutub al-‘Alamiyah, 2000.

M. Quraish Shihab, Tafsir al-Misbah: Pesan, Kesan, dan Keserasian al-Qur'an, Volume: 1, Jakarta: Lentera Hati, 2004.

Ngalimun, Strategi dan Model Pembelajaran, Yogyakarta: Aswaja Pressindo, 2013.

Richard Hamilton dan Elizabeth Ghatala, Learning ang Instruction, New York: McGraw-Hill, 1994.

Sharon E. Smaldino, Instructional Technology dan Media For Learning: Teknologi Pembelajaran dan Media Untuk Belajar, Jakarta: Kencana, 2012.

Suharsimi Arikunto, Prosedur Penelitian Suatu Pendekatan Praktik, Jakarta: Rineka Cipta, 2006.

Syofian Siregar, Metode Penelitian Kuantitatif: Dilengkapi Perhitungan Manual dan SPSS, Jakarta: Kencana, 2014.

Undang-Undang RI Nomor 14 Tahun 2005 Tentang Guru dan Dosen, Jakarta: Sinar Grafika, 2008.

W. Gulo, Strategi Belajar Mengajar, Jakarta: Gramedia Widya Sarana Indonesia, 2002.

Yatim Riyanto, Paradigma Baru Pembelajaran: Sebagai Referensi Bagi Guru Pendidik dalam Implementasi Pembelajaran Yang Efektif dan Berkualitas, Jakarta: Kencana, 2009. 
Al-Muaddib : Jurnal Ilmu-Ilmu Sosial \& Keislaman http://jurnal.um-tapsel.ac.id/index.php/al-muaddib/

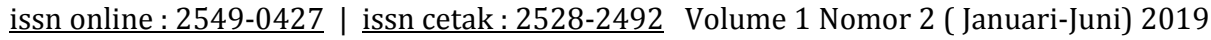

Wina Sanjaya, Strategi Pembelajaran Beriorentasi Standar Proses Pendidikan, Jakarta: Kencana, 2010.

Margaret E. Gredler, Leraning and Instruction: Teori dan Aplikasi, Jakarta: Kencana, 2011. 